\title{
EXPLORING TEACHER STRATEGIES IN TEACHING DESCRIPTIVE WRITING IN INDONESIA
}

\author{
${ }^{1}$ Sufatmi Suriyanti \& ${ }^{2}$ Aizan Yaacob \\ School of Education and Modern Languages \\ Universiti Utara Malaysia, Malaysia \\ ${ }^{2}$ Corresponding author: aizan904@uum.edu.my
}

\begin{abstract}
Purpose - This paper is the outcome of a study which examined teacher strategies in teaching descriptive writing to junior high school students in Delitua, North Sumatra, Indonesia. The study was based on two questions: 1) What are the teaching strategies used by EFL teachers in teaching descriptive writing? 2) To what extent did the descriptive writing intervention change the EFL teacher teaching strategies?
\end{abstract}

Methodology - The qualitative data were obtained from observations, interviews and student writing. An intervention conducted with four teachers for four months using Spencer's Writing Model (2005) to enhance the teaching of writing strategies was examined. The data were recorded, transcribed verbatim and analyzed using thematic coding.

Findings - The findings revealed that the teachers used limited strategies in teaching writing due to their lack of knowledge and understanding of the writing approaches. However, after the writing intervention, they improved their instructional strategies by incorporating richer writing descriptions which contained sensory details, figurative language and vivid words.

Significance - These findings can be used as teaching guidelines for EFL writing in any teacher professional development programmes. Training of teachers could be a starting point not only to increase teachers' knowledge and skills in teaching writing but also to increase their awareness of the beliefs about teaching and learning. 
Our study provided evidence that training can bring about changes in teachers' pedagogical practices which in turn, will lead to a more meaningful learning environment for their learners.

Keywords: EFL, Descriptive writing, Teacher Strategies, Junior High School, Pedagogy

\section{INTRODUCTION}

Writing in English as a foreign language (EFL) appears to be an excruciating experience for many students not only in Indonesia, but also in Malaysia, Thailand, Japan and other countries (Foo, 2007; Kaewnuch, 2008; Kamimura, 2010; Zheng, 1999) and teaching writing is a difficult task for many teachers. Some obstacles in EFL writing such as the learners' lack of skill of the English structure, the limited choice of words, and the influence of culture have been reported by many researchers in the field (Ghabool, Marriadas \& Kashed, 2012; Kaewnuch, 2008; Kamimura, 2010; Wong, Chin, Chen \& Gao, 2009). Apart from that, the teacher factor may also influence the teaching of EFL writing. Teacher beliefs about writing approaches will somehow determine how the writing skill is taught in the classroom. If a teacher believes in producing the final product with an error-free writing, he or she will spend a lot of time teaching the grammatical structures or editing the errors made by the students, rather than on the process itself. Furthermore, the lack of knowledge, skills and appropriate training in teaching EFL writing makes the teachers teach using the traditional product approach model with a heavy reliance on the textbook (Adeyemi, 2008; Akinwamide, 2011; Alnufalie \& Grenfell, 2012; Ariyanti, 2010; Foo, 2007; Pennington, 1995; Somsak, 2008; Wong et al., 2009; Zeng, 2010;). Earlier studies indicated that there were many approaches used in teaching ESL/EFL writing. Badger and White (2000) claimed that for over 20 years product and process approaches have dominated much of the teaching of writing that happens in EFL classrooms. Similarly, Nunan (1999) stated that a half century ago, writing teachers were mostly concerned with the final product of writing or the product approach, focusing on the "finished product", i.e., the coherent and error-free text produced by the students. 
Product and process approaches are the two most common approaches in teaching writing. In the product approach the teachers teach writing by focusing on the grammatical correctness, and the lexical patterns. Accuracy in writing is given greater emphasis than the content itself. Harmer (2002) stated that the aim of the writing task and its final product were the point of importance of this approach. Besides, the teacher is often too demanding about grammatical correctness and focuses primarily on the language structure (Leki, 1990) and sentence level grammar (Nunan, 1999). The writing tasks of product-oriented approach were typically imitating, copying, and transforming models provided by the teachers or text books.

The Product approach has been applied in countries where English is considered as a second or a foreign language, such as Indonesia (Ariyanti, 2010), Singapore (Pennington, 1995), China (Wong et al., 2009; Zeng, 2010), Malaysia (Foo, 2007), Northern Africa (Adeyemi, 2008), Thailand (Somsak, 2008) and many others. These studies revealed that the writing teachers were mostly concerned with the final product of writing, which focused on the coherent and error- free text produced by the students. As a result, students became passive and dependent on the teachers. It was also argued that this approach neglected the processes involved during writing, i.e., how the students wrote, how they generated ideas, and how they produced their piece of writing (Raimes, 1983; Tribble, 1996).

The Process approach on the other hand, gives priority to how the writing process evolved, whereby it guides the students on how to write, generate ideas, proof write and edit their work. Tribble (1996), one of the founders of the process approach, emphasized that it was, 'an approach to the teaching of writing which stresses the creativity of the individual writer, and which pays attention to the development of good writing practices rather than the imitation of models' (p.160).

Hedge (2011) has explained the 'recursive nature' of writing which involved "getting ideas together, planning and outlining, making notes, making the first draft, revising, planning, drafting, and finally editing, and getting ready for publication" (p.3). In process writing, students are free to choose the topics that they want to write about with some guidance from the teachers and they do not fear writing, because the main focus in writing is not on achieving grammatical 
correctness, but on the way students write. Studies have shown that the writing produced by EFL students using the process approach was much better (Dheram, 1995; Raimes, 1983) because creativity in writing was emphasized (Tribble, 1996).

\section{Teaching Writing in Indonesia}

Descriptive, narrative, expository and argumentative writings are the four most common types of writing (Richards \& Schmidt, 2002). However, among these four modes of writing, descriptive writing is the most basic form of writing. At first glance, it seems simple for an academic discourse, yet it is "fundamental and the best way to lay the foundation of the writer's craft" (Meyers, 2009, p.245). In addition, all types of writing encompass some elements of descriptive writing that cause a reader to see, think, feel, and react (Meyers, 2009). It incorporates a colorful piece of a person, a place, a thing, or an idea using concrete and also vivid details (Axelrod and Cooper, 2001; Carrell, 2001; Johannessen, 1995; McCarthy, 1998; Spencer, 2005). Therefore, each mode of writing activates different types of processes in the mind of the writers and it follows different procedures.

In Indonesia, descriptive writing is one of the types of writing that should be taught and mastered not only by the English teachers, but also by the junior high school students, particularly those in Grades Seven, Eight and Nine. In 2006, the Indonesian English Language Curriculum made it compulsory for the students to be able to write different types of texts and one of them is the descriptive text (Departemen Pendidikan Nasional, 2006). Descriptive writing has been re-emphasized in the English Language Curriculum (2013) but this time with greater emphasis on integrating moral values. As such, the new development in the English Language Curriculum has created much stress among EFL teachers in Indonesia and it has become a demanding task for them since there are many components that must be mastered such as grammar, spelling, content, conjunction, choice of words, and sentence arrangement to produce a unified paragraph (Kurt \& Atay, 2007; Raimes, 1983; Tribble, 1996; Zheng, 1999). Sensory details, such as the sense of sight, sound, smell, taste, and touch, along with figurative language such as simile, personification, metaphor and also vivid words are some of the components that 
must be applied in teaching descriptive writing (Axelrod \& Cooper, 2001; Johannessen, 1995; Manery, 2003; McCarthy, 1998; Spencer, 2005). Sensory details are important to create an intense, descriptive image that seems to bring the words on the page to life (Axelrod \& Cooper, 2001). Even though descriptive writing has become one of the most important skills, apart from narrative and expository writing as outlined in the English Language Syllabus in Indonesia (Departemen Pendidikan Nasional, 2006; 2013), it has often been overlooked by language teachers (Hedge, 2011).

Earlier studies have indicated that most Indonesian teachers faced some problems in teaching writing (Ariyanti, 2010; Rozimela, 2004; Wahyuni, 2003). Wahyuni (2003) for instance, indicated that teachers tended to focus on the grammatical structures and gave less attention to the writing process due to their limited knowledge in teaching writing. In addition, Rozimela (2004) mentioned that teaching writing was difficult and the most complex skill, therefore it was often put aside or neglected by teachers. She reiterated that students were given sample texts to copy and were not provided steps on how to write effectively. This phenomenon did not only occur in Indonesia, but was also found in other EFL contexts (Adeyemi, 2008; Pennington, 1995; Wong Chin, Chen \& Goa, 2009; Somsak, 2008; Zeng, 2010). In addition, most of the Indonesian student writing styles was very much influenced by their mother tongue which is the Indonesian language. Besides, writing is said to be more dependent on the use of linguistic resources of language, resulting in difficulties experienced by ESL/EFL learners, especially at the elementary and secondary levels (Ariyanti, 2010; Graham\& Harris; 2005).

\section{Descriptive Writing Strategies}

There are many descriptive writing strategies used in teaching such as the models introduced by Johannessen (1995), Manery (2003), McCarthy (1998), and many others. However, among them, Spencer's SFV Model (2005) was adopted because it provided the most detailed description of descriptive writing strategies for EFL learners. SFV is the short form of Sensory details, Figurative language and Vivid words, aspects which are all essential in writing descriptive essays (Johannessen, 1995; Manery, 2003; Spencer, 
2005). Figure 1 illustrates the SFV Model used in this study. This model consists of three processes which are free writing, whilst writing and post writing. In the free writing process, the techniques of brainstorming and mind mapping are introduced and whilst writing involves the detailed description of the descriptive writing elements. The post writing includes the processes needed after writing is done such as revising and presenting the essay.
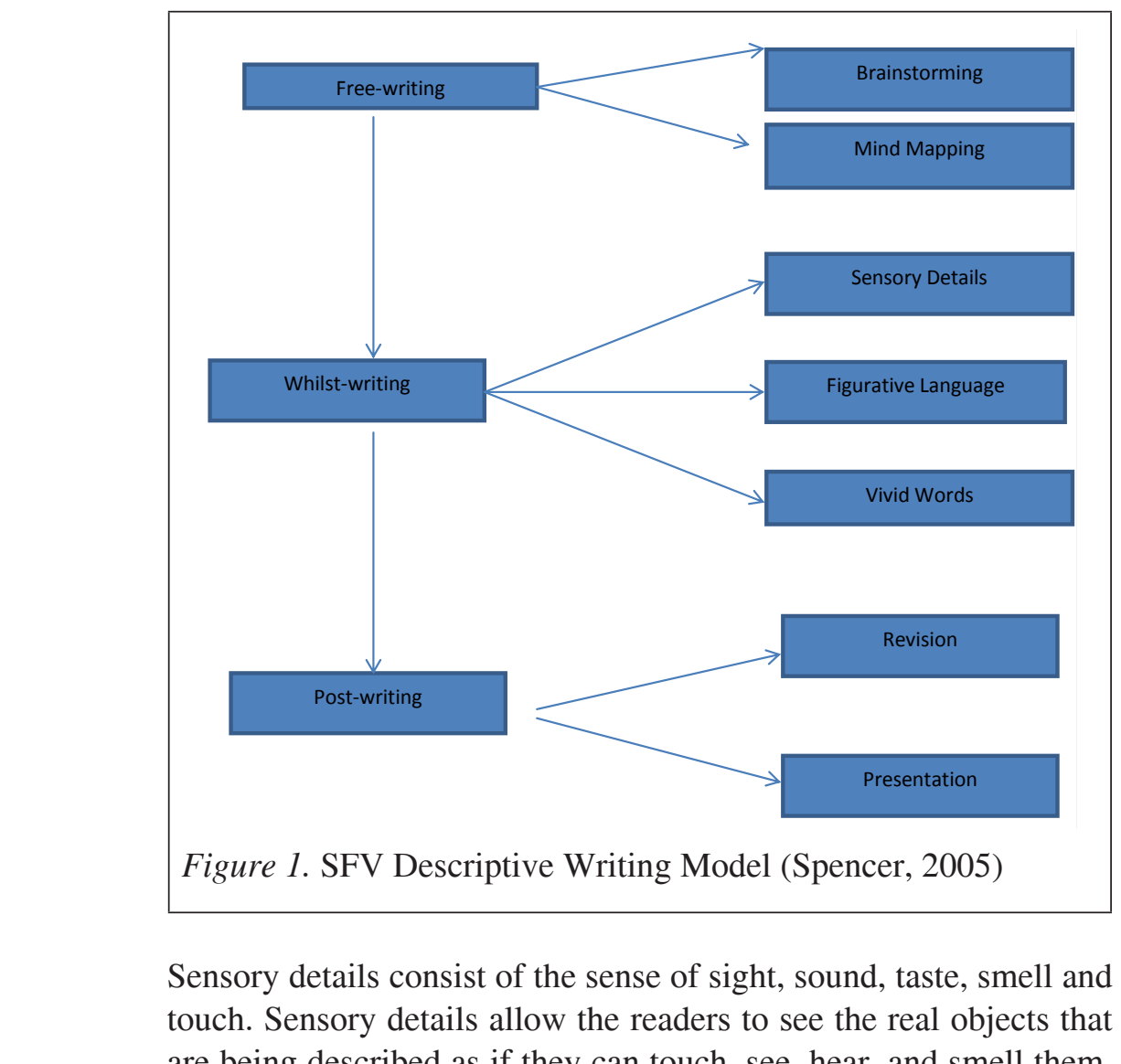

Sensory details consist of the sense of sight, sound, taste, smell and touch. Sensory details allow the readers to see the real objects that are being described as if they can touch, see, hear, and smell them. Figurative language on the other hand, consists of similes, metaphor, hyperbole and personification, while vivid words are specific words which entail in descriptive writing (Spencer, 2005; Manery, 2003; Johannessen, 1995). Spencer (2005) stated that descriptive writing depended on details and colourful language to bring a subject to life. By describing a person, a place or an object with vivid details, a writer can create a descriptive scene in the readers' mind. Similarly, 
Johanessen (1995) suggested that teachers should familiarize students with these terms by providing plenty of vivid examples. Similes on the other hand, are used to compare two different people, places, or things by using the words "like" or "as", such as her beauty is like Cinderella's. Metaphors are also similar to simile, but it does not use the words "like" or "as". For example, "Anny is a flower in my class". The word "flower" means beautiful. Personification is to give human characteristics to something that is not human, for example, "his pen dances on his book". The word "dance" refers to human characteristic, and the word "pen" is considered a live object. A vivid word is a specific modifier, for example, in the sentence "the price of the car is expensive", the word "car" is not vivid enough, so to make it become more vivid, we have to modify the word "car" into "the red proton car" because it vividly elaborates in greater detail the attributes of the car. All of the explanations above can be applied in teaching descriptive writing, and it will make student descriptive writing become more interesting and lively.

Even though there are many studies that looked into the ways teachers teach writing in EFL contexts, more attention has been paid to the needs of students learning to write rather than to teachers learning to teach (Cheung, 2011; Lee, 2010). There are still limited studies on teachers learning to teach writing. Moreover, earlier studies did not employ writing intervention to support teachers in learning to teach. More research needs to be conducted in this area. On the one hand, writing is often neglected in the classroom and on the other hand, EFL teachers often do not receive adequate training in writing assessment and instruction (Dempsey, Pytlikzillig \& Burning, 2009). Thus, this study attempts to explore the Indonesian teacher strategies in teaching descriptive writing and to analyse the effectiveness of the teaching intervention conducted by them.

\section{Research Questions}

The study carried out wanted to answer the following research questions:

1. What are the teaching strategies used by Indonesian EFL teachers in teaching descriptive writing?

2. To what extent did the descriptive writing intervention change the EFL teachers' teaching strategies? 


\section{METHODOLOGY}

As this is part of a larger study on exploring the Indonesian EFL teachers' teaching writing strategies, the qualitative data were obtained from observations, interviews and student writing. Convenient sampling was applied in this study (Gall, Gall \& Borg, 2007: p.175). Gall et al. (2007) claimed that the sample can be convenient for a variety of reasons such as the site being familiar to the researcher and more importantly, the sample suits the purposes of the study. Although there were six English teachers in the school where the research was carried out, only four English teachers participated because two of them had to withdraw due to time constraints. This consideration was made based on the Code of Ethics and Conduct which was organized around four principles: respect, competence, responsibility and integrity. Braun and Clarke (2013) stated that there was "the need for self-determination which means that the participants know about their right to withdraw from research during or after it has taken place" (p.62). All of these teachers taught in the seventh, eigth and ninth grades. However, in this paper, we will report only the findings from the observations and interviews before and after the intervention. The observation data for this paper were taken from one teacher known as Teacher ETIS. The rationale for doing this is that the observation data obtained from all the teachers were rich to the extent that they became 'saturated' (Braun \& Clarke, 2013) which means that 'the new data stop generating any substantially new ideas" (p.336). As such the researchers felt that by highlighting the observation data from one teacher in this paper particularly, is sufficient to allow us to see the changes made to the teaching after the intervention. As for the interview findings, other teachers' comments were included to support the data from the observation.

\section{Participants}

Table 1 indicates the profile of the participants involved in this study.

Based on Table 1, there were four (4) Indonesian secondary school teachers involved in this study and they were referred to as ETIS, ETID, ETPS and EKTK. Three of them were females and one was male. They were teaching in the state secondary schools in 
Indonesia. All of them had a bachelor's degree in English and all of them had been teaching English for more than 10 years. Their teaching experience ranged between ten (10) and twenty five (25) years.

Table 1

Profile of the participants

\begin{tabular}{llllll}
\hline No & Participants & Gender & Age & Years of Experience & Type of schools \\
\hline 1 & ETIS & Female & 35 & 10 years & Public school \\
2 & ETID & Female & 38 & 10 years & Public school \\
3 & ETPS & Female & 37 & 10 years & Public school \\
4 & ETKT & Male & 51 & 25 years & Public school \\
\hline
\end{tabular}

\section{School}

One school was selected in this study based on purposeful sampling (Creswell, 2013). It was a State Junior Secondary School in Delitua, North Sumatera Indonesia which was located about ten (10) kilometers from Medan city. There were six English teachers teaching in the school. There were twenty four (24) classrooms which consisted of eight (8) classrooms for seventh grade, eight (8) for eighth grade and eight (8) for ninth grade. The seventh and eighth grade teachers were involved in this study.

\section{Methods}

This study adopted a qualitative approach using multiple methods that included observations, interviews, document analyses and field notes. The observation was used to explore the teaching strategies used by the teachers. The observation was conducted in two phases: before and after the intervention which took place within four months. Each observation lasted for 45 minutes and they were recorded and transcribed for analysis. Interviews with the teachers were conducted twice before and after the intervention to identify their views regarding descriptive writing strategies that they used in the classroom and the effectiveness of the teaching intervention. 


\section{Procedures}

This study involved three stages of data collection over six (6) months. In Phase 1, preliminary observations and interviews were conducted to examine the nature of writing practices in the classrooms of the participants. In the second phase of the study, eight (8) interventions were conducted with the teachers for over two months and each time the intervention lasted for two hours. The training was conducted by one of the researchers who was a teacher educator at one of the universities, and also an English teacher in the area. The researcher's role in this study was as an observer participant.This means that the researcher observed how the teachers taught descriptive writing before and after intervention, and how the teachers participated in the training itself. According to Harland (2010), "there is evidence that the teacher (as researcher) is best placed to research their own practices rather than rely on knowledge from others" (p.8). In the training, the teachers were briefed on the aims of the study and the procedures involved. They were also briefed on the ethical issues. The teachers were also introduced to various descriptive writing models such as those of Spencer, (2005), McCarthy, (1998), Johannessen, (1995), and Manery (2003). They were provided with examples of sensory details, involving the sense of sight, sound, smell, taste and touch. For example, these included the sense of sight such as colours (red, black, reddish, purple), size (big, small, tall, and so forth), figurative language, vivid words, and other SFV terms. Relevant materials such as notes and handouts were given to the teachers during the training. In Phase 3, a post observation was conducted to examine whether the teachers have applied the training strategies in their teaching, followed by an interview of its effectiveness.

\section{Data Analysis}

All the observation and interview data were recorded, transcribed and analysed using emergent coding. First of all, the researchers read and reread the results of interview, classroom observation, field notes, and the documents. The analysis involved coding, categorizing and labeling whereby the data were divided into manageable units, then synthesized for patterns and reduced into themes for the narratives (Creswell, 2013). 


\section{RESULTS}

\section{The Nature of Teaching Strategies Used by EFL Teachers before the Training}

Table 2 shows the teaching strategies used by the teachers before the training was conducted.

Table 2

Teaching Strategies Used by the Teachers before Training

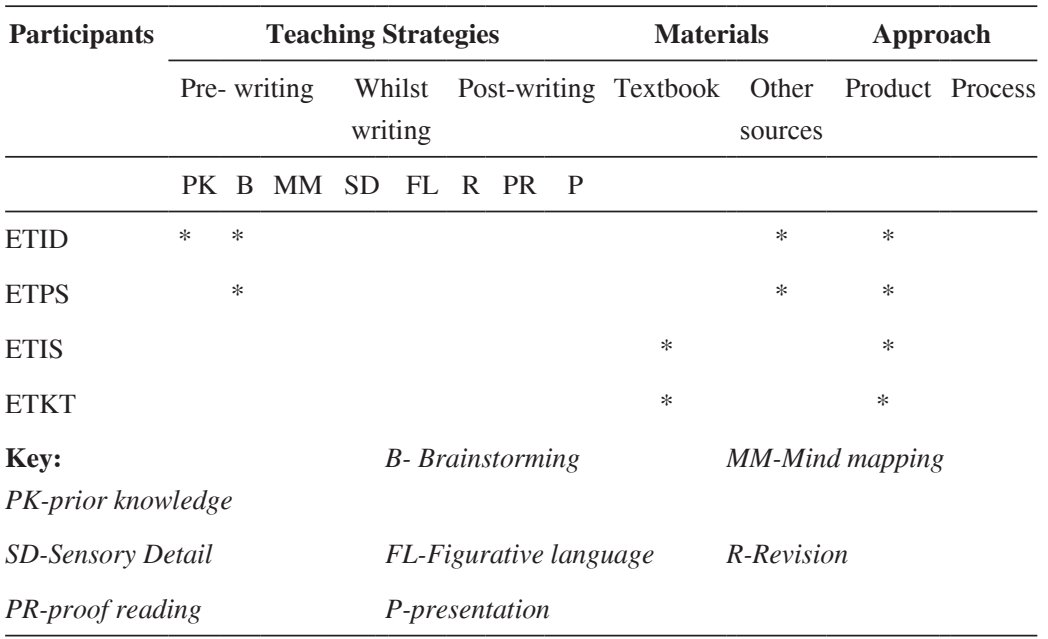

Table 2 reveals that all the four teachers (100\%) applied a product approach in their writing class using either a text book or other reading materials. Two teachers (ETIS and ETKT) were text book oriented whereby they provided examples from the textbook and asked students to copy texts in their writing book. In relation to teacher teaching writing strategies, limited strategies were used, such as using prior knowledge and brainstorming in the pre-writing stage. None of them used any strategies in the whilst and the post writing stages.

Extracts 1 and 2 further illustrate the writing practices of one female teacher ETIS, who had ten (10) years of teaching experience. 


\section{Extract 1: ETIS' Writing Lesson prior to training}

\begin{tabular}{|c|c|c|}
\hline Line & Interaction & Text \\
\hline 1 & $\mathrm{~T}$ & Good morning students \\
\hline 2 & SS & Good morning mom \\
\hline 3 & $\mathrm{~T}$ & How are you today? \\
\hline 4 & SS & Fine mom \\
\hline $\begin{array}{l}5 \\
6\end{array}$ & $\mathrm{~T}$ & $\begin{array}{l}\text { Ok open your English book page } 50 \text {. This text discusses about } \\
\text { descriptive text. Sudah Nampak halamannya? }<\text { have you } \\
\text { found the page?> }\end{array}$ \\
\hline 7 & SS & Sudah $<$ yes $>$ mom \\
\hline Line & Interaction & Text \\
\hline $\begin{array}{l}8 \\
9\end{array}$ & $\mathrm{~T}$ & $\begin{array}{l}\text { Sekarang kita membaca teks deskripsi } \text { singkat }<\text { now we } \\
\text { read the short descriptive text }>\text {...bacadulu } \mathrm{H}<\text { read first } \mathrm{H}>\text {. }\end{array}$ \\
\hline 10 & $\mathrm{H}$ & ANTO IS A JUNIOR HIGH SCHOOL STUDENT. HE \\
\hline 11 & & GOES TO SMP 6.EVERYDAY HE GOES TO SCHOOL \\
\hline 12 & & ON FOOT. ANTO LIKES READING BOOK AND HE \\
\hline 13 & & GOES SWIMMING EVERY WEEK. HE NEVER COMES \\
\hline 14 & & LATE TO SCHOOL. HE ALWAYS RESPECT AND OBEY \\
\hline 15 & & HIS PARENTS AND HIS TEACHER. ( $\mathrm{H}$ reads the text in \\
\hline 16 & $\mathrm{~T}$ & the textbook) \\
\hline 17 & & Ok di sini< $<$ ok here $>$. Anto is a junior high school apa itu \\
\hline 18 & $\mathrm{~S}$ & maksudnya? $<$ what does that mean?> \\
\hline 19 & $\mathrm{~T}$ & Anto seorang pelajar SMP $6<$ Anto is an SMP 6 student $>$ \\
\hline 20 & & Everday he goes to school on foot.Setiap hari dia pergi seko- \\
\hline 21 & $\mathrm{~S}$ & $\begin{array}{l}\text { lah }<\text { everyday he goes to school }>\text {. On foot apa ertinya }<\text { what } \\
\text { is the meaning }>\text { ? } \\
\text { Jalankaki<walk }> \\
\text { (ETIS-1) }\end{array}$ \\
\hline
\end{tabular}

What can be seen in Extract 1 is that ETIS had asked the students to read a short text about Anto from the text book (lines 10-14) and then her students to provide meanings of certain English words such as "junior high school' (line 16) and 'on foot" (line 19). Most of the explanation was conducted in Bahasa Indonesia (L1).

The observation data also revealed that ETIS used limited strategies in teaching descriptive writing. She used the text prescribed in the textbook and generally asked her students to read aloud the text and to answer either comprehension questions or to get the meaning of some difficult words. The observation data also clearly indicated 
that ETIS used Bahasa Indonesia (L1) in her instructions to clarify the meaning of words for her students.

In the interviews, ETIS and the other teachers admitted that writing was the most difficult skill to teach because it involved grammar, content, organization and vocabulary. They mentioned their lack of understanding and knowledge on the writing approaches as well as the components of descriptive writing when asked in the interview. Below are some of the interview findings:

\section{Writing is a difficult process}

All four teachers (100\%) explained that writing was the most difficult skill to teach. ETPS mentioned that students needed to master grammar, while ETIS and ETKT felt that vocabulary needed to be taken into consideration apart from other components.

Writing is difficult because in writing we should master grammar..a sentence..tenses etc...(ETPS Interview 1)

Ya paling sulit menulis karena banyak yang harus diperhatikan seperti bentuk waktu kosa kata kurang dan yang lainnya<the most difficult is writing because there are many things to be taught such tenses, limited vocabulary and others>

\section{(ETIS Interview 1)}

ETKT further added that writing was even more difficult when vocabulary was limited. In addition, ETID explained that the writer needed to know the procedures, content, grammar and vocabulary in writing.

Menulis paling sulit apalagi kalau kosa kata kurang, grammarnya lagi menyusunnya lagi<writing is the most difficult what more if the vocabulary is limited...the grammar and the organization... $>$ (ETKT Interview 1) 
harus tahu prosedurnya tensesnya kata kerja berapa yang harus dipakai yang diceritakan itu apakah sekarang atau sudah lewat $<<$ feel that teaching writing is the most difficult from the four skills because we have to know the procedures tenses action verbs how many to use and whether the story is at present or in the past>(ETID Interview 1)

\section{Lack of understanding on process and product approach}

The interview findings indicated that these teachers lacked understanding and knowledge of the process and product approaches. ETIS admitted that she did not understand the product and process approaches.

Saya tak faham apa itu $<I$ don't understand what is $>$ product andprocess approach...baru ini saya dengar <only now $I$ heard about it $>$ (ETIS Interview 1)

They also misunderstood the meaning of product and process approach. ETID explained that product was the outcome of an essay and teaching was done using a product, while process was an expansion of the text itself and students were taught steps in writing. ETID thought that as the approach has the word 'product', writing meant producing a product. ETIS on the other hand mentioned that product approach focused on the students' final writing product without any known process.

Produk...setiap pengajaran harus ada produknya dari produk tersebut kita ciptakan pelajaran selanjutnya... process approach ya pengembagan dari teks yang kita berikan kepada siswa $<$ I think product approach is teaching by using product there is no step in teaching and then process approach in teaching by using process we teach our studentswith some steps $>$ (ETID Interview 1)

product approach bertumpu pada hasil tulisan siswa tanpa ada proses yang diketahui<centers around the product of students' writing without any known process $>$ (ETIS Interview 1) 


\section{Lack of understanding on descriptive writing components}

All the teachers (100\%) also mentioned their lack of knowledge on the components of descriptive writing and that they had never heard about any of the terms used such as sensory details, vivid words, and figurative language.

Sensory detail saya tidak tahu...<I don't know $>$ vivid words and figurative language saya juga tidak tahu $<I$ also don't know $>$ (ETIS Interview 1)

I'm sorry mom I have never heard about that...I know the words but I don't know vivid words (ETKT Interview 1)

Sensory details is the tenses we use in present tense... kurang faham tentang gitu<don't quite understand $>$ (ETPS Interview 1)

Kurang tahu mungkin dari artinya secara mendetail menjelaskan sesuatu kurang faham apa itu vivid words and figurative language < don't know perhaps from the meaning it says explain in detail...don't quite understand what it is $>$ (ETID Interview 1)

In a nutshell, teachers reported that writing was the most difficult skill to be taught. Besides, their lack of knowledge and understanding about the product and the process approaches led to misunderstanding of the concept and the meaning of those approaches.

\section{The nature of writing after the training}

After undergoing training for two (2) months, the teachers' strategies in teaching descriptive writing were observed. Table 3 shows the teaching strategies used by the teachers after the training. As indicated, all the teachers $(100 \%)$ managed to incorporate all the teaching strategies during pre-writing, whilst writing and post writing. However, not all of the teachers applied the same strategies in teaching descriptive writing, even though all of them used the SFV model. 
Table 3

Teaching Strategies Used by the Teachers after Training

\begin{tabular}{|c|c|c|c|c|c|c|c|c|c|c|c|c|}
\hline \multirow[t]{3}{*}{ Participants } & \multicolumn{8}{|c|}{ Teaching Strategies } & \multicolumn{2}{|c|}{ Materials } & \multicolumn{2}{|c|}{ Approach } \\
\hline & \multicolumn{3}{|c|}{ Pre- writing } & \multicolumn{2}{|c|}{$\begin{array}{c}\text { Whist } \\
\text { writing }\end{array}$} & \multicolumn{3}{|c|}{ Post-writing } & \multirow[t]{2}{*}{ Textbook } & \multirow[t]{2}{*}{$\begin{array}{c}\text { Other } \\
\text { sources }\end{array}$} & \multicolumn{2}{|c|}{ Product Process } \\
\hline & PK & B & MM & SD & FL & $\mathrm{R}$ & PR & $\mathrm{P}$ & & & & \\
\hline ETID & $*$ & $*$ & $*$ & $*$ & $*$ & $*$ & $*$ & $*$ & & & $*$ & $*$ \\
\hline ETPS & * & * & * & $*$ & * & $*$ & * & $*$ & & & $*$ & * \\
\hline ETIS & $*$ & $*$ & $*$ & $*$ & $*$ & $*$ & $*$ & $*$ & & & $*$ & $*$ \\
\hline ETKT & * & $*$ & * & $*$ & * & $*$ & * & $*$ & & & * & * \\
\hline
\end{tabular}

ETIS for example, applied all of the knowledge she had learned in the training whereby she started the lesson by providing the example of descriptive writing contained in the SFV model to her students. Next, she asked one of the students to read it, and then she explained the aim of descriptive writing, sensory details, figurative language and vivid words found in the example provided. After explaining them she asked the students to produce descriptive writing containing sensory details, figurative language and vivid words.

All of the teachers explained and gave examples of sensory of sight, sound, touch, taste and smell, and the teachers guided the students to express their ideas using sensory details. The teachers also explained about figurative language, such as simile, metaphor and personification. Extract 2 illustrates ETIS' writing lesson after the training. Extract 2 illustrates how ETIS had improved her teaching strategies by incorporating SFV in her lesson.

In Extract 2, ETIS explained all of the knowledge she had gathered from the training, but she also applied different strategies. Firstly, she explained about sensory details (Lines 9-11), figure of speech (lines 26-28) and vivid words. Next, she guided the students to write a descriptive essay. The teacher was also found to give some examples of metaphor (lines 29-30) and hyperbole to illustrate the points she was making. For example, "Her face is as round as ball, her smile is like an angel (line 28), Ali is a lion in his village (line 29) and her pen dances on her paper (line 30). Interestingly, the lesson was observed to be more lively and interactive as the teacher 
and the students co-constructed the meaning of the text even though some of it was done in Indonesian language. The data also revealed that the training managed to reduce the teacher's traditional way of teaching writing. There were no more reading aloud and answering comprehension question activities observed after the training.

\section{Extract 2:ETIS' Writing Lesson After the Training}

\begin{tabular}{|c|c|c|}
\hline Line & Participation & Text \\
\hline 6 & \multirow[t]{2}{*}{$\mathrm{T}$} & Ok good. To make descriptive writing more interesting we should \\
\hline 7 & & apply sensory details. Do you know what is sensory detail? \\
\hline 8 & Ss & No mom \\
\hline 9 & \multirow[t]{6}{*}{$\mathrm{T}$} & \multirow{7}{*}{$\begin{array}{l}\text { Ok, I will explain it. Sensory details consist of sensory of sight, } \\
\text { smell, touch, sound, and tasteFor example if we want to describe } \\
\text { people, we describe that he is handsome. It meant we use our eyes } \\
\text { to describe him. It is called sensory of sight.. Another example, } \\
\text { we touch something and it is rough, it is called sensory of touch, } \\
\text { Have you understood? Ok please give another example sensory } \\
\text { of sight, }\end{array}$} \\
\hline 10 & & \\
\hline 11 & & \\
\hline 12 & & \\
\hline 13 & & \\
\hline 14 & & \\
\hline 15 & Ss & \\
\hline 16 & \multirow[t]{2}{*}{$\mathrm{T}$} & Color, blue, black, yellow mom \\
\hline 17 & & Ok right and many others. Ok how about sensory of smell, please \\
\hline 18 & $\mathrm{~S}$ & give example \\
\hline 19 & $\mathrm{~T}$ & Sweet, pahit $<$ bitter $>$ mom \\
\hline 20 & Ss & Ok, good. Sensory of touch? \\
\hline 21 & $\mathrm{~T}$ & Soft, banyak bulu mom $<$ much feathers $>$ \\
\hline 22 & Ss & Ok, how we translate it? Ada yang tahu? <anyone knows> \\
\hline 23 & $\mathrm{~T}$ & No mam \\
\hline 24 & Ss & Ok, beside sensory details, there is another term, that is figurative \\
\hline 25 & \multirow[t]{13}{*}{$\mathrm{T}$} & language. \\
\hline 26 & & Do you know what is figurative language? \\
\hline 27 & & No mom \\
\hline 28 & & \multirow{10}{*}{$\begin{array}{l}\text { Ok figurative language in Indonesian language is gaya } \\
\text { bahasa<stylistic }>\text {. For example simile, metaphor and hyperbole. } \\
\text { The example of simile use "as" or "like",. Her face is as round as } \\
\text { ball, her smile is like an angel. The example of metaphor is Ali } \\
\text { is a lion in his village, it meant Ali is a brave man in his village. } \\
\text { Next the example of hyperbole " her pen dances on her paper. } \\
\text { It meant pen is considered a living thing, because "dance" only } \\
\text { can be done by human not un living thing. Ok now give another } \\
\text { example of them } \\
\text { ETIS, Observation Data }\end{array}$} \\
\hline 29 & & \\
\hline 30 & & \\
\hline 31 & & \\
\hline 32 & & \\
\hline & & \\
\hline & & \\
\hline & & \\
\hline & & \\
\hline & & \\
\hline
\end{tabular}

The observation data were also supported by the interview findings which clarified that the teachers had understood the strategies in teaching descriptive writing. They mentioned that they gained much knowledge about it, and they would continue to apply the model they had learned in the training. They claimed that they knew more about teaching descriptive writing. 
I know many how to teach descriptive writing, before this training I don't know product and process approach and many others terms in teaching descriptive writing. I know the definition and character of descriptive text, sensory details, vivid words and figurative language.(ETKT, interview 2)

I get more knowledge about process, brainstorming, mind mapping, sensory details, figure of speech, revision and proof reading (ETID, interview 2)

I think this training is very essential to the teachers so I hope there's another training about the others. Absolutely it improved my knowledge so much (ETPS Interview 2)

I like this training because it can improve my knowledge I need another training to improve my knowledge (ETID Interview 2)

\section{DISCUSSION}

The study set out to explore teacher strategies in teaching descriptive writing and to evaluate the effectiveness of SVF Model in helping EFL teachers. It revealed that the teachers were unable to use appropriate strategies in teaching descriptive writing due to their lack of understanding and knowledge on the writing approaches as well as the lack of strategies in teaching descriptive writing. Teachers also reported that writing was the most difficult skill to teach and these findings were in line with earlier research that found writing as the most difficult skill to be taught in EFL contexts (Adeyemi, 2008; Ariyanti, 2010; Wong et al., 2009; Foo, 2007; Pennington, 1995; Somsak, 2008; Zeng, 2010). In line with the statement above, EFL teachers in this study, seemed to focus on finishing the materials and ignoring the process involved in writing. Teachers focused only on one component such as the grammatical structure of the language and gave less attention to other essential components of writing (Hyland \& Lo, 2007; Lee, 2010; Wahyuni, 2003). These English teachers still used the product approach in teaching writing due to their limited knowledge on writing strategies, even though studies have indicated the movement towards the process approach. Our study also indicated that these EFL teachers applied the techniques 
of copying examples from the text and transforming the model essay into their own writing. As a result, students became dependent on the teachers and they were not free to express their ideas in the writing task.

However, after participating in the writing intervention, the EFL teachers gained more knowledge about writing, not only on how to teach writing well, but also to become aware of the development of process writing. Teachers in this study acknowledged that they became more knowledgeable after receiving the training. This study has provided evidence of the effectiveness of the SVF Model as used by these teachers in teaching descriptive writing. They started their writing class with brainstorming, mind mapping and they used sensory details, figurative language, vivid words, peer revisions and other techniques in their writing lessons. One of the advantages of applying the process approach in teaching descriptive writing is that the students now know what they want to write, and if the teachers apply the process approach regularly, the students will be able to apply it more, and their writing will improve. This finding resonates with earlier studies (Hyland \& Lo, 2007; Raimes, 1983; Tribble, 1996) which had made the claim that process writing stressed on generating ideas, proof reading and editing and these processes had enabled students to write better.

Our study also showed that writing intervention managed to enhance the EFL teachers' teaching strategies. Richards and Farrel (2005) claimed that teacher trainings needed to provide support for teachers in their teaching of writing. It is situated within the Sociocultural Theory (Vygotsky) framework that emphasizes the role of language and how meaning and understanding can grow out of social interaction. In this intervention, the learning situation set up by the teachers would enable their students to learn collaboratively via scaffolding whereby teachers and students learned with each other's help some effective strategies in teaching and learning writing. One might wonder why some teachers still used the traditional product approach when others have shifted to the process approach which had been shown to be more effective in developing students' writing? Could this be due to the lack of training received by them or the lack of knowledge about changing their beliefs about teaching? Changing teachers' beliefs about teaching is difficult. However, 
hearing teachers' comments and sharing their concerns may be fruitful in changing their beliefs about teaching and learning. The training of teachers could be a starting point to increase teachers' awareness of the beliefs about teaching and learning. Awareness of the shift in the theory of learning from the Piagetian to the Vygotskian, from the importance of action to the importance of language also needs to be fostered through both pre-service and in-service training of the teachers (Yaacob, 2006, p.240). Our findings revealed that teachers managed to apply the strategies taught and they were aware of the skills necessary for teaching descriptive writing. Besides, they became more confident in their teaching as evidenced in the post observation. This is in line with earlier studies that indicated the importance of improving teaching writing competence as they have an impact on students' learning (Ashton \& Webb, 1986; Dembo \& Gibson, 1985; Ross \& Bruce, 2007; Ross, 1998; Soodak \& Podell, 1996; Tschannen-Moran \& Hoy, 2007). As teachers applied the process approach by using the SFV model, the students' descriptive writing improved. They knew how to start writing, how to apply the sensory details, vivid words and figurative language and thus, their writing became more effective. Most importantly, they were no longer afraid to write as the emphasis was on the process and not on grammatical accuracy.

\section{IMPLICATIONS AND SUGGESTIONS FOR FUTURE RESEARCH}

The Process writing approach enables the meaning making process to take place. The nature of the process writing which promotes development of language use (Tribble, 1996; Hedge, 2011) such as brainstorming, revising, editing and generating ideas is found to be effective in this study. When teachers facilitate learning using the process approach, students' writing improved and when the teachers apply the SFV Descriptive Writing Model, students gained ownership in their writing. Lightbown as cited by Steele (2016) stated that learning appeared to be optimal when students knew what they wanted to say and what they wanted to write and they developed an awareness that they were writing for the readers. As such, this study confirms the benefits of the SFV Descriptive Writing Model and the process writing approach. 
Even though this study is limited to only one school in Indonesia, and the results cannot be generalized, we feel that this model can be used as a tool to enhance EFL teachers' teaching strategies. Teachers should be made aware of the various kinds of writing available and the writing strategies to be taught to students. Teachers needed support not only in terms of knowledge, but also in terms of the technical skills or techniques in implementing new approaches. The researchers are of the view that the findings will be useful for the Indonesian Education Department since the SFV model can become a model for teaching descriptive writing in Indonesia. The SFV model has been tested and modified to suit the needs of the Indonesian teachers. The researchers would like to propose that future studies should look into a larger scale of research on writing practices with more teachers from various parts of Indonesia so that a comprehensive view of the phenomenon will be fully understood. Besides, there is a need to use both qualitative and quantitative data to produce an in-depth and generalizable study. Random sampling and longitudinal design can improve the validation of the findings.

\section{NOTES}

\section{Transcription Convention}

Bold- Bahasa Malaysia

Normal - English

Bold Italic-dialect or non- standard spelling

$<$ Italic $>$ Englih Translation

( ) - non- verbal behavior

(...) - pause for a few seconds

CAPITAL LETTERS - reading from the text

XXX unclear conversation

\section{REFERENCES}

Adeyemi, A, D. (2008). Approaches to teaching English composition writing at junior secondary schools in Bostwana (Unpublished doctoral dissertation), University of South Africa. 
Ariyanti, L. (2010). Teaching writing by using the Think-Pair-Share (TPS) technique. In Cahyono, Y. B. (Ed.). The teaching of English language skills and English language components. East Java: State University of Surabaya.

Akinwamide, K. T. (2012). The influence of process approach on English as second language students' performances in essay writing. English language Teaching, 5(3), 16-29. Retrieved from www.ccsenet.org/elt.doi.10.5539/elt.v5n3p16.

Alnufale, M., \& Grenfell, M. (2012). EFL students' writing strategies in Saudi Arabian ESP writing classes: Perspectives on learning strategies in self-access language learning. SISAL Journal, ISSN 2165 -3762. Retrieved from sisal journal.org/ archives/dec 12/alnufalie-Grented.

Ashton, P. T., \& Webb, R. B.(1986). Teacher's sense of efficacy and standard achievement. New York: Longman.

Axelrod, B. J., \& Cooper. R. C. (2001). The St. Martin's guide to writing. USA. Bedford

Badger, R. , \& White, G. (2000). A process genre approach to teaching writing. ELT Journal, 34 (2), 153-160.

Braun, V., \& Clarke, V. (2013). Successful qualitative research: A practical guide for

beginners. London: Sage Publication.

Carrell, A. J. (2001). Writing and grammar, communication in action. USA: Prentice Hall.

Cheung, Y. L. (2011).Teacher training for effective writing instruction: Recent trends and future directions.ProcediaSocial and Behavioural Sciences Journal, 15, 531-534

Creswell, J.W. (2013). Qualitative inquiry and research design: Choosing among five approaches (3rd ed.). Thousand Oaks: Sage Publications.

Dembo, M. H., \& Gibson, S. (1985). Teacher's sense of efficacy: An important factor inschool improvement. The Elemantary School Journal, 86 (2), 173-184.

Dempsey, S. Michael, Pytlikzillig, M. L., \& Burning, H. R. (2009). Helping preservice teachers learn to assess writing: Practice and feedback in a web-based environment. Assessing Writing Article, 14(1), 38-61.

Departemen Pendidikan Nasional.(2006). Standard kompetensi mata pelajaran Bahasa Inggeris sekolah menengah atas (Standard of competence for senior high school). Jakarta. 
English Language Curriculum (2013). Komendiknas: Kempetensi dasar Kementerian Pendidikan Nasional Republik Indonesia. Jakarta.

Dheram, P. (1995). Feedback as a two-bullock Cart. ELT Journal, 49 (2), 160-180.

Foo, V. C. T. (2007). The effect of process genre approach to writing instruction on the expository essays of ESL students in Malaysian secondary school (Unpublished doctoral dissertation).

Gall, M. D., Gall, J, P. , \& Borg, W. R. (2007). Educational research. An introduction (8th ed.). USA: Pearson Education Inc.

Ghabool, N. E, Marriadas, M. A. P. , \& Kashed, H. S. (2012) . Investigating Malaysian ESL students' writing: Problems on conventions, punctuation, and language use at secondary school level. Journal of Studies in Education, 2, 3.

Graham, S., \& Harris, K. R. (2005). Improving the writing performance of young struggling writers: Theoretical and pragmatic research from the center on accelerating student learning. Journal of Special Education, 39, 19-33.

Harland, T. (2010). Practitioner action research for studying higher education and improving the quality of teaching. Malaysian Journal of Learning and Instruction, 7, 1-13.

Harmer, J.( 2002). The practice of English language learning. Edinburg: Pearson Education Limited.

Hedge, T. (2015). Process writing. Centre for English Language Studies. The University of Birmingham. Retrieved from www.birmingham.ac.uk/Document/college_artslaw/cels/ essays/languageteaching/the processApproachGhosal.pdf

Hyland, F., \& Lo, J. (2007). Enhancing students' engagement and motivation in writing: The case of primary students in Hong Kong. Journal of Second Language Writing, 16, 219-237.

Johannessen, L. R. (1995). Teaching descriptive/narrative writing strategies for middle and secondary students. Paper presented at a teachers' institute inservice program at Indian Prairie Community unit school district 204 . Eric Document. No. ED 379665

Kaewnuch, S. (2008). Teaching agency and power as social: Creating transformative subjects in the classes of modernity and post modernity in Thai EFL writing classrooms (Unpublished doctoral dissertation). 
Kamimura, T. (2010). An attempt to help Japanese EFL students writers make the transition from the knowledge telling model to the knowledge transforming model of writing. Senshu. Journal of Foreign Language Education, 38, 29-52.

Kurt, G., \& Atay, D. (2007).The effects of peer feedback on the writing anxiety of prospective Turkish teachers of EFL. Journal of Theory and Practice in Education, 3 (1), 12-23.

Lee, I. (2010). Writing teacher education and teacher learning: Testimonies of four EFL teachers' writing. Journal of Second Language Writing, 19(3), 143-157.

Leki, I. (1990). Coaching from the margins: Issues in written response. In B. Kroll (Ed.), Second language writing: Research insights for the classroom (pp. 57-68). Newyork: Cambridge University Press.

Manery, R. (2003).Cosmic oranges: Observation and inquiry through descriptive writing and art. Marcopolo Education Foundation.: National Council of Teachers of English Urbana, IL.: International Reading Association, Newark, DE. (ERIC Doc. No. ED 477994 Mar 6, 2003.

McCarthy, T. (1998). Descriptive writing, mini lessons, strategies, activities.USA: Scholastic Incorporation.

Meyers, A. (2009). Writing with confidence (9th ed). USA: Pearson Education Inc.

Nunan, D. (1999). Second language teaching and learning. Boston: Henle \& Henle

Pennington, M. C. (1995). The teacher change cycle. TESOl Quarterly, 29 (4). 705-751.

Raimes, A. (1983). Techniques in teaching writing. Oxford: Oxford University Press.

Richards, J. C. and Schmidt, R. (2002). Dictionary of language teaching and applied linguistics in London. London: Pearson Education Limited.

Richards. C. J., \& Farrel. S. C. T. (2005). Professional development for language teachers: Strategies for teacher learning. New York: Cambridge University Press

Ross, J. A. (1998). The antecedents and consequences of teacher efficacy. Advances in Research on Teaching, 7, 49-73.

Ross, J., \& Bruce, C. (2007). Professional development effects on teacher efficacy: Results of Randomized Field Trial. The Journal of Educational Research, 101 (1), 50-60. 
Rozimela, Y. (2004). The value of writing skills in the senior high schools in Indonesia. In Y. B. Cahyono (Ed.), The Tapestry of ELT and language in Indonesia. Malang: State University of Malang.

Soodak, L. and Podell, O. (1996). Teacher efficacy toward the understanding of a multifaceted construct. Teaching and Teacher Education, 12 (4), 401-411.

Somsak, K. (2008). Teaching agency and power as social: Creating transformative subjects in the classes of modernity and post modernity in Thai EFL writing classrooms. Proquest Dissertations and Theses.

Spencer, L. (2005). A step by step guide to descriptive writing. NewYork: Rose Publishing Group Inc.

Steele, V. (2016). Product and process wiring: A comparison. Retrieved from https://www.teachingenglish.org.uk/article/ product-process-writing-a-comparison.

Tribble, C. (1996). Writing. Oxford: Oxford University Press.

Tschannen-Moran., \& Hoy, A. W. (2007). The differential antecedents of self-efficacy beliefs of novice and experienced teachers. Teaching and Teacher Education, 23, 944-956.

Wahyuni, A. D. (2003). The students' descriptive writing as a result of implementation of document portfolio (Unpublished doctoral dissertation). Surabaya: State University of Surabaya.

Wong, L. H, Chin, C. K, Chen W., \& Gao, P. (2009). V-s-p-o-w: An innovative collaborative writing approach to improve Chinese as L2 pupils linguistic skill.

Yaacob, A. (2006). Malaysian literacy in English: Big books; CDroms and the year 1 English hour. University of Warwick (Unpublished doctoral dissertation).

Zeng, H. L. (2010). Investigation and analysis of current writing teaching made among English majors in normal universities in China. On line submission US - China Education Review, 7(8), 22-27.

Zheng, Y. (1999). Providing the students with effective feedback in the writing process. Teaching English in China, 36, 41-45. 